\title{
Simulasi Proses Pemotongan Bubut Baja Karbon Rendah Aisi 1018 dengan Mesin Bubut Menggunakan Metode Elemen Hingga
}

\author{
Mustafid Amna Rambey, Mas Irfan P. Hidayat dan Wikan Jatimurti \\ Departemen Teknik Material dan Metalurgi, Fakultas Teknologi Industri, Institut Teknologi \\ Sepuluh Nopember (ITS) \\ e-mail: masirfan.ph@gmail.com
}

\begin{abstract}
Abstrak-Tegangan dan gaya pada permukaan material dan perkakas potong dihasilkan oleh sudut dan kedalaman potong vang berbeda. Secara khusus dua analisis berbeda dilakukan untuk membandingkan pengukuran gaya potong dan tegangan geser yaitu dengan kedalaman, sudut potong, dan tipe pemotongan tertentu. Proses simulasi permesinan dilakukan dengan menggunakan alat potong single point High $S$ peed $S$ teel (HSS ). S elama proses machining deformasi sangat terkonsentrasi di zona yang sangat kecil dan tegangan yang dihasilkan di zona deformasi mempengaruhi benda kerja dan alat. Telah cukup banyak penelitian yang ditujukan untuk mengembangkan model analitis dan model numerik untuk mensimulasikan proses pemotongan logam untuk memprediksi efek dari variabel machining seperti kecepatan, feed, kedalaman pemotongan dan juga geometri alat dalam deformasi. Analisa dilakukan pada material benda keria AIS I 1018 mild steel dengan menggunakan perkakas potong AISI T15 High Speed Steel. Variabel yang digunakan pada penelitian ini antara lain adalah sudut sernih (rake angle) $-15^{\circ}, 0^{\circ}$, dan $15^{\circ}$, kemudian kedalaman potong yaitu $1 \mathrm{~mm}$ dan $1.5 \mathrm{~mm}$, dan yang terakhir adalah membandingkan dua tipe pemotongan yaitu orthogonal (tegak lurus) dan oblique (miring). Pada penelitian ini telah diteliti bagaimana gaya potong dan tegangan geser pada perkakas potong dan material uji pada saat proses pemotongan dan menggunakan metode smooth particle hydrodinamics. Dari hasil simulasi menunjukkan penurunan gaya potong terjadi ketika sudut serpih perkakas mengalami penurunan dari $15^{\circ}$ ke $-15^{\circ}$, Nilai tegangan maksimum diamati memiliki nilai tertinggi pada sudut $15^{\circ}$ dengan kedalaman potong $1.5 \mathrm{~mm}$. Proses simulasi juga telah dilakukan untuk mengamati pengaruh dari kedalaman potong dan tipe pemotongan.
\end{abstract}

Kata kunci-Perkakas potong single point, alat HSS, Analisis Elemen Hingga, Tegangan, Gaya Potong, Smooth Particle Hydrodinamics.

\section{PENDAHULUAN}

$\mathrm{P}$ ROSES pemotongan dengan logam merupakan suatu proses yang digunakan untuk mengubah bentuk suatu produk dari logam (komponen mesin) dengan cara memotong. Prinsip pemotongan logam dapat didefenisikan sebagai sebuah saksi dari alat potong yang dikontakkan dengan sebuah benda kerja untuk membuang permukaan benda kerja tersebut dalam bentuk geram [1]. Proses pemesinan yang menggunakan perkakas potong bermata tunggal, mekanismenya adalah dengan memotong bagian dari benda kerja bentuk silinder yang berputar. Perkakas dihantarkan secara linier, sejajar dengan sumbu rotasi. Proses pemesinan berdasarkan bentuk benda kerja ada dua, yaitu bentuk bulat (silindris) dan berbagai bentuk non-silindris. Proses pembuatan dilakukan dengan cara memotong sebagian benda kerja yang berputar pada mesin sementara pisau potongnya diam. Analisis mekanisme pembentukan geram tersebut dikemukakan oleh Merchant berdasarkan teorinya atas model pemotongan sistem tegak (orthogonal system). Sistem pemotongan tegak merupakan penyederhanaan dari sistem pemotongan miring (obligue system) dimana gaya diuraikan menjadi komponen gaya yang bekerja pada suatu bidang. Pemotongan tegak (Orthogonal cutting) merupakan suatu sistem pemotongan dengan gerakan relatif antara mata pahat dan benda kerja membentuk sudut potong tepat $90^{\circ}$ atau yang dinamakan dengan sudut potong utama $(\mathrm{Kr})$, dan besarnya lebar mata pahat lebih besar dari lebar benda kerja yang akan dipotong. Sudut geram mempengaruhi proses pembentukan geram pada proses pemotongan orthogonal. Untuk suatu kecepatan potong tertentu, sudut geram yang besar akan menurunkan rasio pemampatan tebal geram $(\lambda \mathrm{h})$ yang mengakibatkan kenaikan sudut geser $(\Phi)$. Jenis material benda kerja juga akan mempengaruhi pemilihan sudut geram. Pada prinsipnya, untuk material yang lunak dan ulet (soft and ductile) memerlukan sudut geram yang besar untuk mempermudah proses pembentukan geram, sebaliknya bagi material yang keras dan rapuh (hard and brittle) memerlukan sudut geram yang kecil atau negatif untuk memperkuat pahat [2].

Pengembangan model bahan berdasarkan torsi dan tes bar dinamis Hopkinson atas berbagai laju regangan dan suhu. Pada dasarnya keuntungan dari model analitis daripada metode empiris murni adalah, pada suatu material baru data eksperimen dibutuhkan untuk menentukan ketergantungan terhadap aliran tegangan pada temperatur, regangan dan laju regangan, dapat dikurangi. Secara ideal, hubungan teoritis diturunkan dari proses fisik pada tingkatan atom seharusnya bisa digunakan untuk mendeskripsikan sifat aliran makroskopis pada material [3]. Karena regangan pada proses pemotongan cukup besar, maka memungkinkan bahwa regangan yang diperoleh dari uji material memiliki nilai yang sama. Ini berarti, mode deformasi dari uji tegangan tidak bisa 
digunakan karena masalah necking. Dengan demikian, metode pembebanan pada uji material seharusnya antara torsional dan tekanan. Metode paling umum digunakan untuk menentukan parameter material untuk model material Johnson-Cook adalah dengan menggunakan Split Hpkinson Pressure Bar Test (SHPB). Untuk menentukan parameter material dibutuhkan beberapa eksperimen dalam material paduan tertentu. Menurut beberapa literatur, model material Johnson-Cook adalah model yang menunjukkan hasil simulasi yang terbaik pada proses pemotongan logam [4].

Smooth Particle Hydrodynamics (SPH) adalah suatu skema yang dikembangkan oleh Lucy, Monaghan dan Gingold Perbedaan utama antara FEM dan metode SPH adalah tidak adanya penyatuan elemen. Pada SPH model didefinisikan sebagai partikel [5].

Pada penelitian ini LS Pre-Post software dipilih untuk memodelkan efek dari berbagai variabel pada proses pemotongan logam terhadap tegangan geser dan gaya potong. ANSYS Mechanical APDL merupakan software bantu dalam simulasi ini dalam proses running.

\section{METODE PENELITIAN}

\section{A. Material yang digunakan}

Material yang digunakan untuk proses pemotongan adalah AISI 1018 Mild Carbon Steel dan untuk perkakas potong digunakan AISI T15 High Speed Steel merupakan material yang didefinisikan oleh standard UNS G10180 dan UNS T12015. Sifat dan komposisi baja AISI 1018 Mild Carbon Steel dan AISI T15 High Speed Steel dapat dilihat pada Tabel $1,2,3$, dan 4 .

Tabel 1.

Properti AISI T15 High Speed Steel

\begin{tabular}{ccc}
\hline \hline Properties & Nilai & Satuan \\
\hline Massa jenis & 8.19 & $\mathrm{~g} / \mathrm{cc}$ \\
Poison Ratio & 0.3 & - \\
Modulus elastisitas & 207 & $\mathrm{GPa}$ \\
Konduktivitas Termal & 20.9 & $\mathrm{~W} / \mathrm{mK}$ \\
\hline \hline
\end{tabular}

Tabel 2.

Komposisi AISI T15 High Speed Steel

\begin{tabular}{ccccc}
\hline \hline \multicolumn{5}{c}{ Komposisi Kimia (\%) } \\
\hline $\mathrm{C}$ & $\mathrm{W}$ & $\mathrm{V}$ & $\mathrm{Co}$ & $\mathrm{Cr}$ \\
1.50 & 12.50 & 4.75 & 4.90 & 4.50
\end{tabular}

Tabel 3

Properti AISI 1018 Mild Carbon Steel

\begin{tabular}{ccc}
\hline \hline Properties & Nilai & Satuan \\
\hline Massa jenis & 7.87 & $\mathrm{~g} / \mathrm{cc}$ \\
Modulus geser & 80 & $\mathrm{GPa}$ \\
Modulus elastisitas & 207 & $\mathrm{GPa}$ \\
Konduktivitas Termal & 51.9 & $\mathrm{~W} / \mathrm{mK}$ \\
Poisson Ratio & & \\
Melting Temperature & 0.29 & - \\
Kapasitas panas & & \\
& 1420 & ${ }^{\circ} \mathrm{C}$ \\
& 470 & $\mathrm{~J} / \mathrm{kg}-\mathrm{K}$ \\
\hline \hline
\end{tabular}

Tabel 4.

Komposisi AISI T 15 High Speed Steel Komposisi Kimia (\%)

\begin{tabular}{cccc}
\hline \hline \multicolumn{4}{c}{ Komposisi Kimia (\%) } \\
\hline $\mathrm{C}$ & $\mathrm{Mn}$ & $\mathrm{S}$ & $\mathrm{P}$ \\
0.17 & 0.70 & 0.05 & 0.04 \\
& & & \\
\hline \hline
\end{tabular}

Tabel 5.

Dimensi Utama Perkakas dan Benda Kerja

\begin{tabular}{ccc}
\hline \hline & Alat Potong & Benda Kerja \\
\hline Bahan & AISI T15 High & AISI 1018 Mild \\
& Speed Steel & Carbon Steel \\
Dimensi & Panjang $-20 \mathrm{~mm}$ & $5 \mathrm{~mm}$ *7 mm*5 mm \\
& Tinggi $-8 \mathrm{~mm}$ & (termasuk sudut \\
& & rake dan clearance \\
& & dari perkakas) \\
& & tool tip :0.2 \\
\hline \hline
\end{tabular}

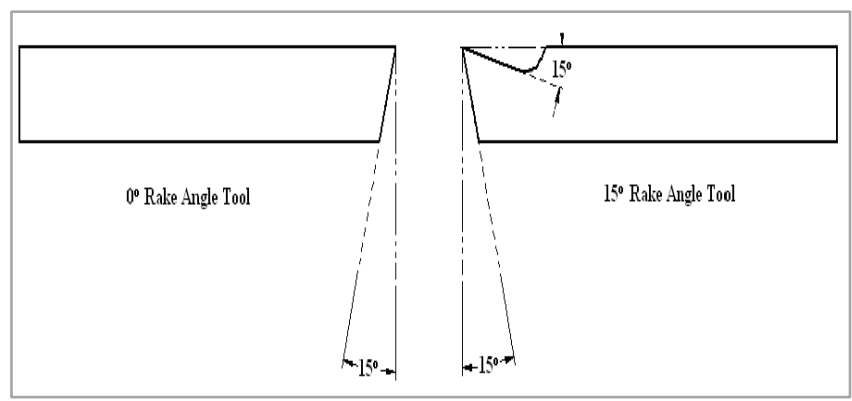

Gambar 1. Perkakas dengan Sudut Potong Berbeda

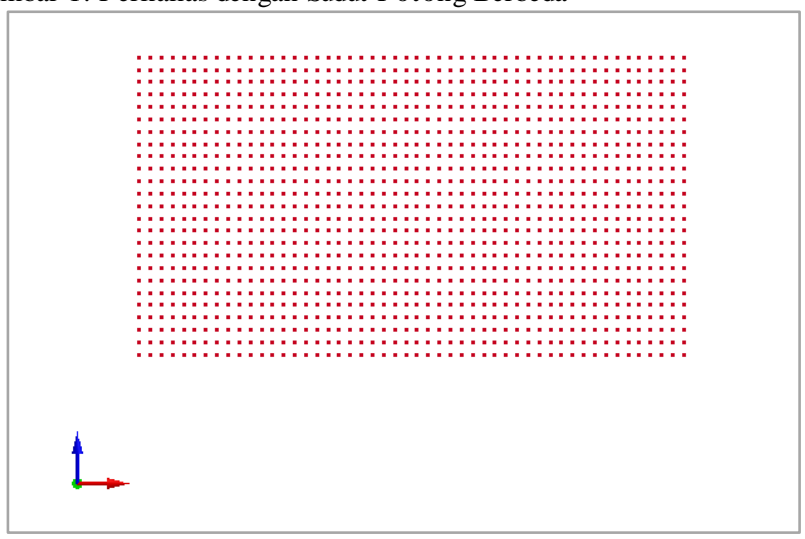

Gambar 2. Benda Kerja AISI 1018 Mild Carbon Steel

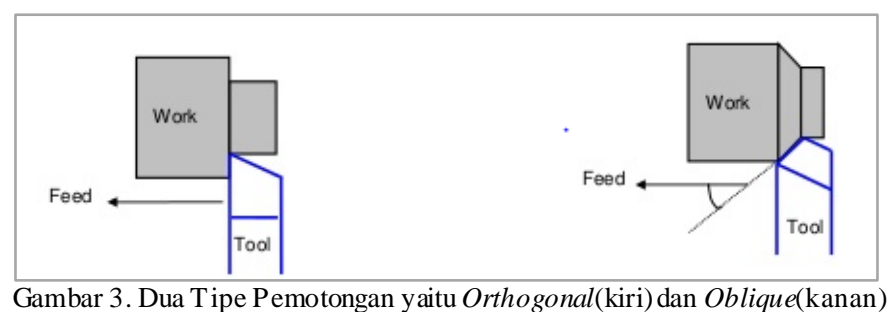

Gambar 3. Dua Tipe Pemotongan yaitu Orthogonal(kiri)dan Oblique(kanan) 


\section{B. Meshing}

Dalam melakukan pemodelan simulasi proses pemotongan metal, langkah pertama yang dilakukan adalah melakukan meshing terhadap material perkakas potong dan benda kerja,

Tabel 6.

Jumlah Elemen Masing-Masing Material

\begin{tabular}{ccc}
\hline \hline No & Mumlah Elemen Masing-Masing Material \\
\hline 1 & Pekakas potong & Jumlah Elemen \\
2 & Benda Kerja & 6734 \\
\hline \hline
\end{tabular}

\section{Penentuan Element Type}

Tipe elemen didefinisikan dari opsi mat dalam keyword manager dibawah tab model and part. Model untuk simulasi ini dibuat dengan menggunakan dua material berbeda yaitu benda kerja dan perkakas potong. Perkakas potong dimodelkan rigid dan model material didefinisikan sebagai johnson-cook. Model ini memprediksi aliran tegangan atas berbagai laju regangan dan suhu berdasarkan persamaan dibawah [3]:

$$
\sigma=\left(A+B \varepsilon^{n}\right)\left(1+C \ln \frac{\dot{\varepsilon}}{\dot{\varepsilon}_{0}}\right)\left(1-\left(\frac{T-T_{r}}{T_{m}-T_{r}}\right)^{m}\right)
$$

\section{Penentuan Sifat Material}

Sifat material dari benda kerja dan alat potong dalam penelitian ini ditentukan dalam LS Dyna menggunakan material model opsi dibawah keyword manager dalam tab model and part. Kriteria pembentukan chip adalah berdasarkan nilai regangan plastis efektif dimana ketika benda kerja mencapai nilai treshold, dihapus, kemudian menyebabkan terpisahnya material menjadi chip.

\section{E. Boundary Condition}

Pada model simulasi, benda kerja di tetapkan pada titik tertentu dan perkakas bergerak ke arah benda kerja dengan kecepatan konstan. Karena benda kerja tidak bergerak, semua degree of freedom ditiadakan termasuk translasi dan rotasi. Degree of freedom dari perkakas juga sepenuhnya ditiadakan untuk semua arah kecuali arah ke sumbu x. Boundary conditions dibuat dengan memilih model and part kemudian keyword manager dimana tab boundary dipilih. Prescribed_motion_rigid dipilih untuk benda kerja dimana semua DOF dibatasi dengan memilih nilai 1 .

\section{HASIL DAN PEMBAHASAN}

\section{A. Analisa Mekanis Sudut Serpih}

Pada bagian ini pengaruh perbedaan sudut serpih pada benda kerja diteliti. Pertama variasi pemotongan dengan sudut serpih $0^{\circ}$ dan $15^{\circ}$ dan $-15^{\circ}$ kedalaman potong $1 \mathrm{~mm}$, dan tipe pemotongan orthogonal digunakan.

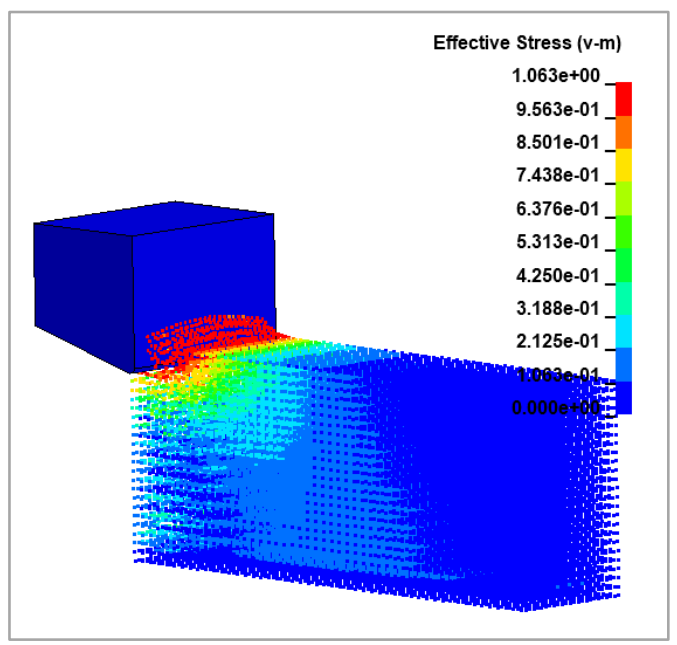

Gambar 4. Persebaran Tegangan Geser Sudut Serpih $0^{\circ}$ Pada Awal Proses Pemotongan

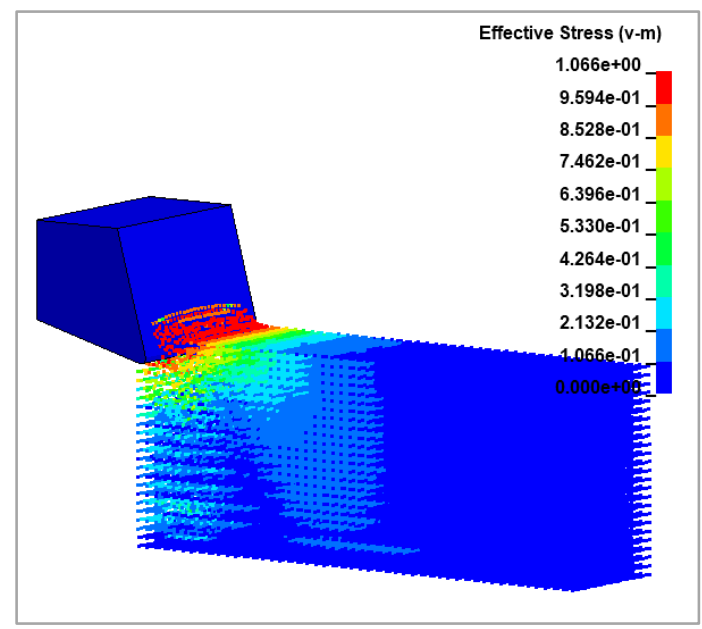

Gambar 5. Persebaran Tegangan Geser Sudut Serpih $15^{\circ}$ Pada Awal Proses Pemotongan

Pada gambar 4. terlihat bahwa bagian ujung perkakas potong menyentuh benda kerja pada daerah ini (memiliki nilai tegangan maksimum sebesar $1.063 \mathrm{Gpa}$. Sedangkan gambar 5 menunjukkan besar tegangan pada serpih $15^{\circ}$ yang memiliki nilai maksimum $1.066 \mathrm{GPa}$. Pada sudut serpih $-15^{\circ}$ tegangan maksimum meningkat menjadi 1.077 GPa karena kontak antara perkakas dan material benda kerja terjadi di area yang lebih luas pada secondary shear zone.

Tabel 7.

Tegangan Geser Pada Awal Pemotongan

\begin{tabular}{cc}
\hline \hline Sudut Serpih & $\begin{array}{c}\text { Tegangan Maksimum } \\
(\mathrm{GPa})\end{array}$ \\
\hline $0^{\circ}$ & 1.063 \\
$15^{\circ}$ & 1.066 \\
$-15^{\circ}$ & 1.077 \\
\hline \hline
\end{tabular}




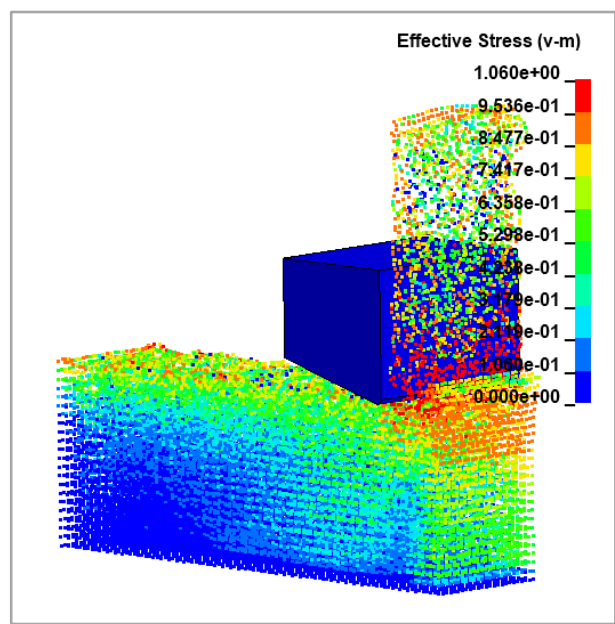

Gambar 6. Persebaran Tegangan Geser Sudut Serpih $0^{\circ}$ Pada Akhir Proses Pemotongan

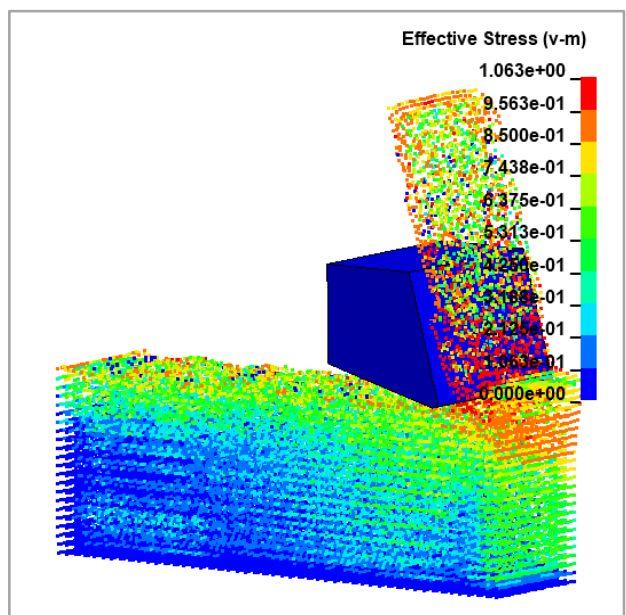

Gambar 7. Persebaran Tegangan Geser Sudut Serpih $15^{\circ}$ Pada Akhir Proses Pemotongan

Pada gambar 6. Pada akhir proses pemotongan nilai tegangan maksimum pada tahap ini adalah 1.060 GPa. Selama proses berlansung nilai tegangan maksimum dengan range antara 1.064 sampai 1.092 , nilai tertinggi tegangan terjadi pada timestep ke 0.70. Dari simulasi juga dapat dilihat bentuk chip yang continue. Untuk sudut $15^{\circ}$ tegangan maksimum pada akhir pemotongan adalah $1.066 \mathrm{GPa}$. Sedangkan range tegangan maksimum selama proses pemotongan adalah antara 1.064 sampai 1.084. Jadi sudut serpih $0^{\circ}$ memiliki nilai tegangan maksimum yang lebih tinggi dibandingkan sudut serpih $15^{\circ}$. Pada akhir pemotongan sudut $15^{\circ}$ nilai tegangan maksimum adalah $1.067 \mathrm{GPa}$. Pada bentuk chip terjadi pemisahan chip karena nilai tegangan yang besar pada secondary shear zone. Pada permukaan benda kerja juga terlihat belum rata . Range tegangan pada keseleruhan proses ini adalah 1.065-1.084 GPa. Pada penelitian juga memperlihatkan pengaruh dari sudut serpih terhadap tegangan maksimum pada benda kerja dimana sudut serpih negatif memiliki nilai tegangan maksimum tertinggi, kemudian diikuti sudut serpih positif, dan terakhir sudut serpih $0^{\circ}[6]$.
Tabel 8.

Tegangan Geser Pada Akhir Pemotongan

\begin{tabular}{cc}
\hline \hline Sudut Serpih & $\begin{array}{c}\text { Tegangan Maksimum } \\
(\mathrm{GPa})\end{array}$ \\
\hline $0^{\circ}$ & 1.060 \\
$15^{\circ}$ & 1.063 \\
$-15^{\circ}$ & 1.067 \\
\hline \hline
\end{tabular}

Dari gambar 6 dan 7 dapat dilihat bahwa semakin negatif sudut serpih perkakas potong maka akan meningkatkan kekasaran permukaaan dari benda kerja hasil proses pemotongan. Hal ini juga dijelaskan pada jurnal bahwa peningkatan sudut serpih juga meningkatkan kekasaran permukaan hasil dari proses pemotongan [7].

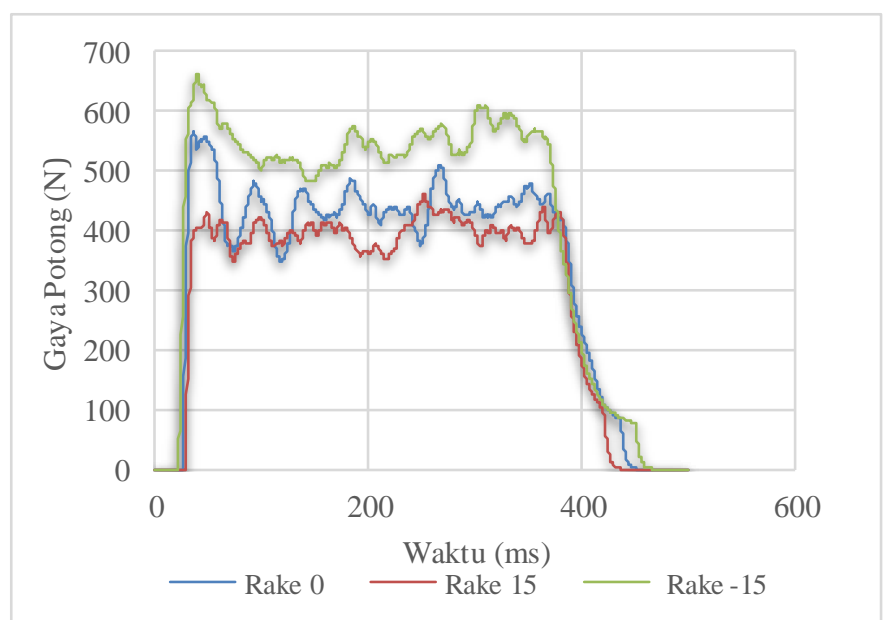

Gambar 8. Persebaran Tegangan Geser Sudut Serpih $-15^{\circ}$ Pada Akhir Proses Pemotongan

Tabel 9.

Gaya Potong Pada Tiga Sudut Serpih

\begin{tabular}{cc}
\hline \hline Sudut Serpih & Gaya Potong $(\mathrm{N})$ \\
\hline $0^{\circ}$ & 395.61 \\
$15^{\circ}$ & 357.93 \\
$-15^{\circ}$ & 464.98 \\
\hline \hline
\end{tabular}

Gambar 8 memperlihatkan perbandingan gaya potong terhadap waktu dimana terjadi peningkatan gaya yang tinggi saat perkakas mulai memotong benda kerja dimana nilai maksimum gaya potong untuk sudut $0^{\circ}$ adalah $608.59 \mathrm{~N}$. Seiring berjalannya waktu gaya potong mengalami kenaikan dan penurunan dan menurun drastis pada saat berakhirnya proses pemotongan. Rata-rata nilai potong untuk proses ini adalah 395.61 N. Sedangkan pada sudut serpih $15^{\circ}$ nilai maksimum gaya potong adalah $489.66 \mathrm{~N}$ dan rata-rata nilai gaya potong sebesar $357.93 \mathrm{~N}$. Pada sudut serpih $-15^{\circ}$ memiliki nilai maksimum gaya potong sebesar $679.24 \mathrm{~N}$ dan rata-rata gaya potong adalah $464.98 \mathrm{~N}$. Dari data tersebut dapat dilihat bahwa dari sudut serpih positif ke negatif maka gaya potong akan semakin besar. Pada penelitiannya melaporkan ketika sudut serpih berubah dari negatif menjadi positif maka gaya potong akan semakin berkurang dimana 
penelitian ini dilakukan dengan membandingkan hasil proses simulasi dan eksperimen [8].

\section{B. Analisa Mekanis Kedalaman Potong}

Pada bagian ini pengaruh perbedaan kedalaman potong diteliti. Variasi pemotongan dengan sudut serpih $15^{\circ}$ kedalaman potong 1 dan $1.5 \mathrm{~mm}$, dan tipe pemotongan orthogonal digunakan.

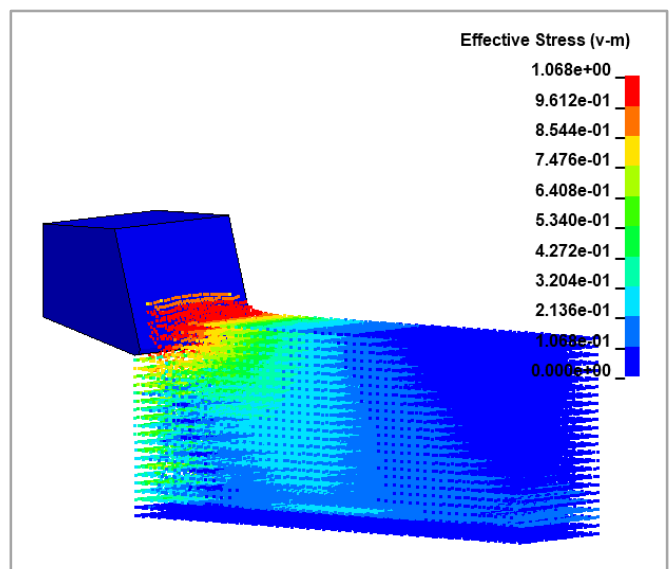

Gambar 9. Persebaran Tegangan Geser Kedalaman 1.5mm Pada Awal Proses Pemotongan.

Tabel 10

Tegangan Geser Pada Awal Pemotongan

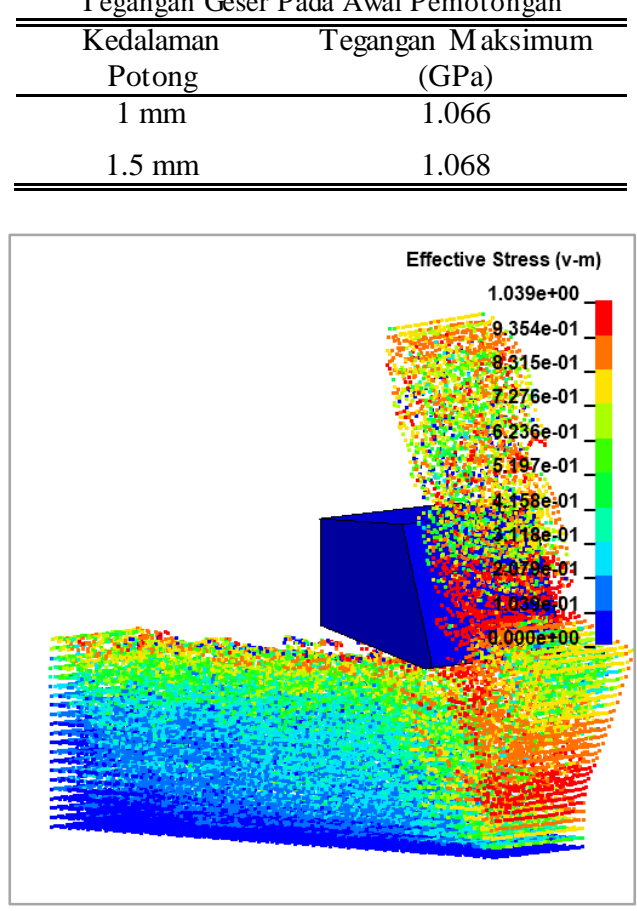

Gambar 10. Persebaran Tegangan Geser Kedalaman 1.5mm Pada Akhir Proses Pemotongan

Tabel 11.

Tegangan Geser Pada Akhir Pemotongan

\begin{tabular}{cc}
\hline \hline $\begin{array}{c}\text { Kedalaman } \\
\text { Potong }\end{array}$ & $\begin{array}{c}\text { Tegangan Maksimum } \\
(\mathrm{GPa})\end{array}$ \\
\hline $1 \mathrm{~mm}$ & 1.060 \\
$1.5 \mathrm{~mm}$ & 1.039 \\
\hline \hline
\end{tabular}

Pada gambar 10 juga menunjukkan kekasaran permukaan yang meningkat daripada kedalaman $1 \mathrm{~mm}$. Hal ini juga disebutkan pada jurnalnya bahwa semakin besar kedalaman potong, maka luas penampang dari chip semakin besar dan berpengaruh terhadap hasil dari proses pemotongan dalam hal ini kelasaran permukaan [7].

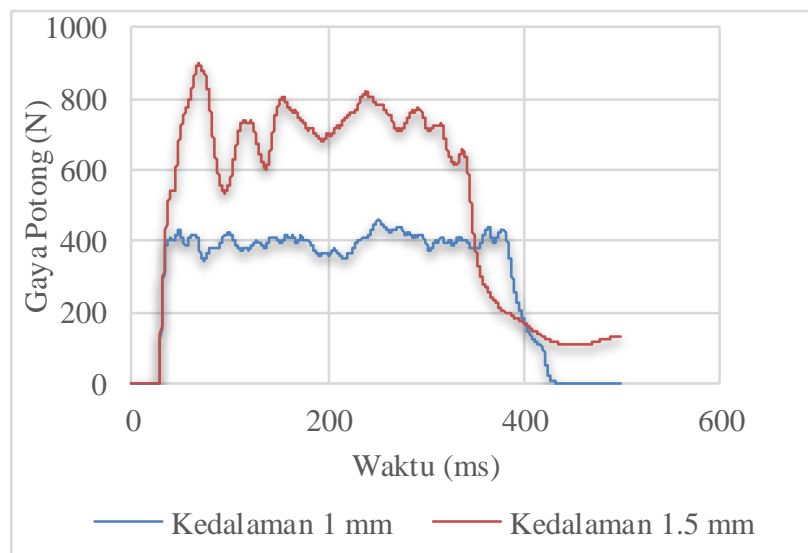

Gambar 11. Perbandingan Gaya Potong Terhadap Waktu Kedalaman Potong Berbeda.

Tabel 12.

Gaya Potong Pada Dua Kedalaman Potong

\begin{tabular}{cc}
\hline \hline $\begin{array}{c}\text { Kedalaman } \\
\text { Potong }\end{array}$ & $\begin{array}{c}\text { Tegangan Maksimum } \\
(\mathrm{GPa})\end{array}$ \\
\hline $1 \mathrm{~mm}$ & 1.060 \\
$1.5 \mathrm{~mm}$ & 1.039 \\
\hline \hline
\end{tabular}

Penggunaan Ls-Dyna untuk mensimulasikan proses pemotongan orthogonal dan menghasilkan ketika sudut serpih dianggap konstan gaya potong meningkat dengan meningkatnya kedalaman potong yang mana hasil eksperimen juga menunjukkan hal yang sama meski nilainya tidak persis [8].

Dapat dilihat dari hasil simulasi diatas bahwa semakin dalam kedalaman potong maka gaya potong akan semakin meningkat hal ini terjadi karena kedalaman potong memiliki pengaruh terhadap gaya potong. Dari persamaan merchant berikut:

$\mathrm{Fc}=\frac{t x b x k \cos (\beta-\alpha)}{\sin \phi \cos (\phi+\beta-\alpha)}$, dimana $\mathrm{Fc}$ adalah gaya potong, $\mathrm{t}$ adalah kedalaman potong, $\mathrm{b}$ adalah lebar chip, $\mathrm{t}$ adalah ketebalan chip yang belum dipotong $\beta$ adalah sudut friksi, $\phi$ adalah sudut bidang geser, dan $\alpha$ adalah sudut serpih [9]. Maka apabila kedalaman potong bertambah dimana pada proses ini dari $1 \mathrm{~mm}$ menjadi $1.5 \mathrm{~mm}$, gaya potong juga akan meningkat.

\section{Analisa Mekanis Tipe Pemotongan}

Ada dua jenis tipe pemotongan yaitu orthogonal (lurus) dan oblique (miring) pada bagian ini dianalisa bagaimana pengaruh dari dua tipe pemotongan terhadap gaya potong dan persebaran tegangan pada benda kerja. Untuk variabel pemotongannya adalah sudut serpih $15^{\circ}$, kedalaman potong $1.5 \mathrm{~mm}$ dant tipe pemotongan oblique (miring). 
Tabel 13.

Tegangan Geser Pada Awal Pemotongan Oblique dan Orthogonal

\begin{tabular}{cc}
\hline \hline Tipe Pemotongan & $\begin{array}{c}\text { Tegangan Maksimum } \\
(\mathrm{GPa})\end{array}$ \\
\hline Oblique & 1.064 \\
Orthogonal & 1.066 \\
\hline \hline
\end{tabular}

Tabel 14

Tegangan Geser Pada Akhir Pemotongan Oblique dan Orthogonal

\begin{tabular}{cc}
\hline \hline $\begin{array}{c}\text { Tipe } \\
\text { Pemotongan }\end{array}$ & $\begin{array}{c}\text { Tegangan Maksimum } \\
(\mathrm{GPa})\end{array}$ \\
\hline Orthogonal & 1.063 \\
Oblique & 1.059 \\
\hline \hline
\end{tabular}

Pada tabel 13 dipeorleh nilai tegangan maksimum adalah $1.064 \mathrm{GPa}$. Nilai tegangan ini tidak jauh berbeda dari tegangan maksimum dari proses pemotongan orthogonal yaitu 1.066 GPa. Persebaran tegangan pada benda kerja menunjukkan persebaran tegaangan yang lebih dalam dari pada proses orthogonal. Pada tabel 14 terlihat bahwa pada akhir proses pemotongan nilai tegangan maksimum adalah $1.059 \mathrm{GPa}$. Nilai ini berkurang dari proses orthogonal yang memiliki nilai 1.063 GPa. Secara keseluruhan proses tipe pemotongan oblique memiliki nilai tegangan yang lebih rendah dari pemotongan orthogonal.

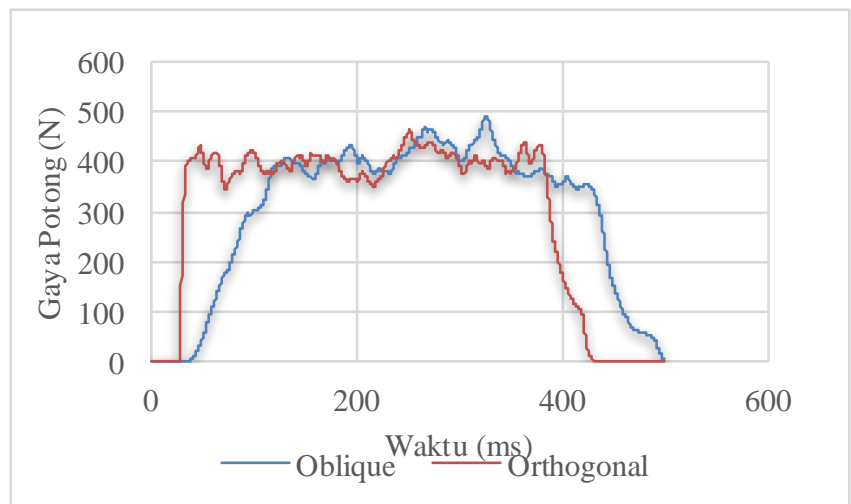

Gambar 12. Perbandingan Gaya Potong Terhadap Waktu Dua Tipe Pemotongan

Tabel 15.

Gaya Potong Pada Dua Kedalaman Potong

\begin{tabular}{cc}
\hline \hline Tipe Pemotongan & Gaya Potong $(\mathrm{N})$ \\
\hline Oblique & 357.93 \\
Orthogonal & 322.26 \\
\hline \hline
\end{tabular}

Pada grafik perbandingan gaya potong terhadap waktu nilai gaya maksimum pada pemotongan oblique adalah $500.8 \mathrm{~N}$ lebih tinggi dari pemotongan orthogonal yang memiliki nilai maksimum 489.66 N. Sedangkan untuk rata-rata nilai gaya potong oblique sebesar $322.26 \mathrm{~N}$.

\section{KESIMPULAN}

Berdasarkan hasil analisis data dan pembahasan yang diuraikan pada BAB IV disertai dengan pembatasan masalah yang digunakan, maka kesimpulan yang diperoleh dari penelitian ini adalah :

1. Penurunan gaya potong terjadi ketika sudut serpih perkakas mengalami kenaikan dari $15^{\circ}$ ke $-15^{\circ}$ Gaya potong meningkat dengan bertambahnya nilai kedalaman potong dari $1 \mathrm{~mm}$ ke $1.5 \mathrm{~mm}$ pada sudut serpih yang konstan. Nilai tegangan maksimum diamati memiliki nilai tertinggi pada sudut $-15^{\circ}$ karena kontak perkakas dan benda kerja pada secondary shear zone yang luas, kemudian diikuti sudut serpih $15^{\circ}$ karena nilai kontak yang tinggi pada primary shear zone antara material dan perkakas potong. Peningkatan nilai tegngan juga terjadi pada pengaruh kedalaman potong dimana tegangan pada $1.5 \mathrm{~mm}$ lebih tinggi daripada $1 \mathrm{~mm}$ chip yang dihasilkan pada $1.5 \mathrm{~mm}$ lebih tebal daripada $1 \mathrm{~mm}$ yang berpengaruh pada nilai pada tegangan geser dimana pada bagian ini nilai tegangan tertinggi terjadi.

2. Gaya potong pada pemotongan oblique dari hasil simulasi menunjukkan nilai yang lebih tinggi daripada pemotongan orthogonal, pada nilai tegangan oblique memiliki nilai tegangan yang lebih rendah daripada pemotongan orthogonal.

\section{DAFTAR PUSTAKA}

[1] Yuliarman, "Studi Pemotongan Optimum Pembubutan Keras Dan Kering Baja Perkakas AISI O1 Menggunakan Pahat Keramik (A12O3 + TiC)," USU Digit. Libr., 2008.

[2] R. T, Proses Permesinan. Jakarta: Higher Educatio Development Support Project, 1993.

[3] W. H. Johnson, G.R. and Cook, “A Constitutive Model and Data for Metals Subjected to Large Strains, High Strain-rates and High Temperatures," in Seventh International Symposium on Ballistics, 1993, pp. 541-547.

[4] J. H. and D. A. T. Jaspers, S. P. F. C. Dautzenberg, "Int J Adv Manufacture Technology: Temperature Measurement in Orthogonal Metal Cutting," Springer, 1998.

[5] L. L.B, "A numerical Approach to Testing the Fission Hypothesis," Astron. J., pp. 1013-1024, 1977.

[6] S. and G. J. Hamed, "Orthogonal Metal Cutting Simulation of Steel AISI 1045 via Smoothed Particle Hydrodynamic Method," in World Congress on Engineering, 2017.

[7] M. L. M. Kuttalamodom, Matthew, Sina Hamzehlouia, "Effect of Machining Feed on Surface Roughness in Cutting 6061 Aluminum," Int. Cent. Automot. Res. Univ., 2010.

[8] V. Vardhan, "Finite Element Simultion of Orthogonal Metal Cutting using LS Dyna," 2011.

[9] M. . Merchant, "Mechanics of the Metal Cutting Process," J. Appl. Phys., vol. 16, pp. 267-275, 1944. 